\title{
A Survey Analysis Of The Resource Selection Models In Agile/Virtual Enterprises
}

\author{
A. Pires ${ }^{* 1}$, G. Putnik ${ }^{2}$, P. Ávila ${ }^{3}$ \\ ${ }^{1,3}$ Department of Mechanical Engineering, Institute of Engineering - Polytechnic Institute of Porto, \\ Rua Dr. António Bernardino de Almeida, 431, 4200-072, \\ Porto, Portugal \\ *ant.man.pires@gmail.com \\ ${ }^{2}$ Department of Production and Systems, University of Minho, \\ Campus de Azurém, 4810-058 \\ Guimarães, Portugal
}

\begin{abstract}
In this work, a survey is made of the analysis of the resource selection process. We approach the process also from the point of view of conventional enterprises but with particular emphasis on the existent models in Agile/Virtual Enterprises in order to identify the main limitations and shortcomings of the process.
\end{abstract}

This analysis was focused in the global process of the resource selection, namely in terms of the pre-selection and selection phases, requisites, mathematical models, tools and other relevant areas in the existent models.

It is concluded that the resource pre-selection is an area that is not adequately explored in a systematic way. The value concept is not incorporated in the selection process. As a result, a reasoned analysis is not performed of the decision-making process for creating an Agile/Virtual Enterprise. These conclusions were made to envision a future approach that allows the incorporation of new areas that contribute to the improvement of the resource selection process.

Keywords: Agile/Virtual enterprises, resource/partner selection models, resource pre-selection, supplier/resource criteria.

\section{RESUMEN}

En este trabajo hacemos un análisis de la encuesta del proceso de selección de recursos. Nos acercamos al proceso también desde el punto de vista de las empresas convencionales pero con especial énfasis en los modelos existentes en Empresas Ágil/Virtuales con el fin de identificar las principales limitaciones y deficiencias del proceso.

Este análisis se centró en el proceso global de la selección de recursos, es decir, en términos de la pre-selección y fases de selección, requisitos, modelos matemáticos, herramientas y otros ámbitos pertinentes en los modelos existentes.

Llegamos a la conclusión de que la pre-selección de recursos es un área que no está suficientemente explorado de manera sistemática. El concepto de valor no se incorpora en el proceso de selección. No se hace un análisis razonado de la toma de decisión de crear una Empresa Ágil/Virtual. Estas conclusiones se hicieron con el fin de vislumbrar un futuro enfoque que permita la incorporación de nuevas áreas que contribuyan a mejorar el proceso de selección de recursos.

\section{Introduction}

For many years, namely in military campaigns, the supply chain and the resource selection has always assumed a large importance. For example, Sun Tzu in its classic "The art of war" already emphasized the relevance of this question [1]. The ability to respond to continuous and unexpected

changes is essential for success in the markets. New types of cooperation between companies emerged including production networks based on varying collaboration and duration.

Market changes, together with continuous technological innovation, have led to a redefinition 
of the additional value chain in a global production network [2]. The main idea behind the production networks is the mutual use of resources and joint planning of processes for adding value [3]. Production networks offer new potential for improving processes to add value [4]. It was the work of Drucker and the lacocca Institute which gave rise to the concept of the virtual enterprise associated with the concept of creating dynamic networks of companies [5, 6].

Thus, market globalization requires companies to continually invest in innovation, competitiveness and excellence. As flexibility is becoming one of the most important requirements of production systems and when a product/service is often produced with contributions from several companies, the concept of Agile/Virtual Enterprises (A/V E) emerged and developed. An A/V E should be a dynamic and virtual structure capable of reacting to a business opportunity in which every company involved, whether wholly or partially, would not lose its unique physical and cultural identity upon deactivation at the end of product life. The development of such more dynamic and complex types of enterprises have led to an upsurge in research interest in the resource selection process. The resultant knowledge should contribute to improve the performance of such enterprises owing to an expansion in the range of potential production resources in comparison with conventional enterprises.

Our reference model of $A / V E$ is based on a hierarchical multi-level process which aims to satisfy the basic properties of a virtual enterprise [7, 8]. These properties should follow the principles of integrability, distributivity, agility and virtuality [9]. Our concept of $A / V E$ is associated with the creation of a temporary network of various physical organizations (or resources) with the intent to develop and produce one or more products/services, in desired quantity and quality, responding to a market solicitation.

\section{Supplier / resource selection in conventional enterprises}

Currently the competition in the global market does not occur between companies but between supply chains. Initially, we will present a review analysis of the existent models of supplier/resource selection in conventional enterprises, in a way to obtain a global and general perspective, namely in terms of the selection methods classification, types of models and extent of the problem. This analysis is done in order to assess the similarities/differences with the $A / V E$ projects and to frame this issue from a global perspective of the inherent problems to the resource selection.

\subsection{Models of Supplier/Resource Selection in Conventional Enterprises}

An extensive literature revision in this area framed the problem in a global form. Although it relates the pre-selection phase that is approached in some of the existing models, it concludes that the great majority of the models essentially approach the final selection phase. The models are divided in two main categories: single resource selection and multiple resource selection [10]. The following table intends to synthesize the classification of the selection models.

We can put into evidence that there is a myriad of methods and mathematical models, some of them used in distinct types of problems. This is an area where the approaches can be diverse. A complete and correct specification of the problem is essential, in order to foresee the type of model indicated for the problem.

The review of the literature in this area enables also to classify the existing models in three categories: elimination, probabilistic and optimization methods [11]. Elimination methods are methodologies that eliminate the candidates who do not satisfy minimum selection requirements or minimum values for these requirements. The probabilistic methods try to foresee futures scenarios for the performance of the resources to select. The optimization methods consider the optimization of an objective function with one or several criteria that can or not have constraints. Once again, we can verify that the approaches to the problem are different and all the methods have advantages and disadvantages. 


\begin{tabular}{|c|c|c|c|}
\hline \multirow{3}{*}{$\begin{array}{l}\text { Single } \\
\text { Resource } \\
\text { Selection } \\
\text { Models }\end{array}$} & Single Criterion & $\begin{array}{l}\text { - Criterion: Price, Quality, Delivery time, } \\
\text { Service, etc) }\end{array}$ & \\
\hline & Multi-criteria & $\begin{array}{l}\text { - Weighting methods } \\
\text { - AHP } \\
\text { - Fuzzy theory }\end{array}$ & \\
\hline & With Uncertainties & $\begin{array}{l}\text { - Probability distributions } \\
\text { - Dynamic programming } \\
\text { - Decision trees }\end{array}$ & \\
\hline \multirow{8}{*}{$\begin{array}{l}\text { Multiple } \\
\text { Resource } \\
\text { Selection } \\
\text { Models }\end{array}$} & $\begin{array}{l}\text { Single and Multiple } \\
\text { Item Models }\end{array}$ & $\begin{array}{l}\text { - Linear integer programming } \\
\text { - Mixed integer programming } \\
\text { - Heuristic methods } \\
\text { - Goal programming } \\
\text { - Non linear programming }\end{array}$ & \\
\hline & $\begin{array}{l}\text { Single and Multiple } \\
\text { Period Models }\end{array}$ & $\begin{array}{l}\text { - Economic order quantity } \\
\text { - Mixed integer programming } \\
\text { - Mixed integer non linear programming } \\
\text { - Genetic algorithm } \\
\text { - Goal programming } \\
\text { - Search algorithm } \\
\text { - Heuristic methods } \\
\text { - Data envelopment analysis }\end{array}$ & \\
\hline & \multirow[t]{2}{*}{$\begin{array}{c}\text { Technique Oriented } \\
\text { Models }\end{array}$} & Single Objective Methods & $\begin{array}{l}\text { - Linear programming } \\
\text { - Mixed integer programming } \\
\text { - Goal programming } \\
\text { - Others (Dynamic program., } \\
\text { non linear program., stochastic } \\
\text { program, decision theory) }\end{array}$ \\
\hline & & Multiple Objective Methods & $\begin{array}{l}\text { - Multi-objective programming } \\
\text { - Goal programming } \\
\text { - Others (neural networks) }\end{array}$ \\
\hline & \multirow{4}{*}{ Alternative Models } & Total Cost Ownership Models & \\
\hline & & Integrated Models & $\begin{array}{l}\text { - Cluster analysis } \\
\text { - AHP }\end{array}$ \\
\hline & & $\begin{array}{l}\text { Efficiency-based Selection and } \\
\text { Negotiation Models }\end{array}$ & $\begin{array}{l}\text { - Multi-objective programming } \\
\text { - DEA }\end{array}$ \\
\hline & & Stochastic Models & $\begin{array}{l}\text { - Stochastic integer progr. } \\
\text { - Fuzzy Theory }\end{array}$ \\
\hline
\end{tabular}

Table 1. Model Types of Supplier/Resource Selection.

The aspect of the weighting on multi-criteria decision processes is currently considered almost consensual in the supplier/resource selection problem [12]. It is treated in models that present a weighted integer programming model or that incorporate a statistic sensitivity analysis [13, 14]. Others consider a model where the Analytic Hierarchy Process (AHP) method is combined with integer programming $[15,16]$. The use of genetic algorithms has also being referred [17, 18, 19]. Several studies present models based on the fuzzy decision process in order to select the most favorable resources, having limited means of evaluation [20]. Others also consider a fuzzy model with support of a genetic algorithm or a weighted fuzzy model combined with mixed integer programming [21, 22].

New contents have been incorporated in the models of suppliers/resource selection like ambient factors, the candidate's individuality or heterogeneity, or issues as flexibility [16, 23, 24]. Another study reports that quality, delivery, financial stability, capacity and partnership are the requisites further discussed in the literature on this topic [25]. Factors like geographic location, interest in the 
business, access to financial markets, added value, management and organization and information systems appear as other important requisites [26]. Others propose seven main criteria: price, quality, delivery time, service level, ordering process, associated technology and financial condition [27], or indicates five key selection criteria: performance, confidence degree, economic factor, social ethics and completeness [28]. The supplier selection decision should meet criteria such as quality, service level and degree of cooperation [29]. Key metrics are: financial indicators, strategic advantages, customers and markets focus, synergies and organizational quality systems [30]. Partnerships, inter-organizational relations and synergies are increasingly important [31]. Other relevant factors are: ability of cooperation; security; trust; information systems; flows control and coordination [32].

Other studies of literature revision list a number of criteria, of which we will refer the most quoted and that pass through: quality, financial strength, location, innovation, price, delivery time, level of service, communication and information systems, flexibility, reputation, partnership relations, and economic factors [33, 34, 35]; or list a number of features to consider such as: organizations culture, service level, credibility, market position, expertise, financial stability, synergy and mutual benefits [36]; or propose three main systems of requisites: financial status, strategy and organizational culture and technological state [37].

Another important approach is based on studies that define three main systems: performance of resource/partner; technical and financial capacity; and quality system [38]. This approach states that the candidate resources that do not meet a minimum of one level of the system are eliminated at this stage of pre-selection. This has already been applied in various ways by other authors; pure knockout rule, by precedence levels of requirements or through method by categories, by classification algorithms and by data envelopment analysis [26, 29, 39, 40, 41, 42, 43].

We can see that there is no conformity between the various authors regarding the criteria to consider. This discrepancy is mainly due to the fact that there are different views and perspectives on the issue.
Studies and literary revisions were analyzed previously, as well as several existent models of the suppliers/resource selection in conventional enterprises. The information collected and analysis will be extremely useful for the main area of our work, the universe of $A / V E$.

\section{Resource/ partners selection in A/V E}

In the context of the intense bibliographical review on this subject, which sometimes is not linear and includes other vectors and different extents, were considered for analysis the models listed in the next tables. These models treat the problem of resource selection in organizations designated as virtual enterprises, or according to our model, agile/virtual enterprises. Priority was given to more comprehensive and explicit models, which include the entire global process. Several of these models incorporate studies and previous investigations. We intend to have an approach exhaustive as possible on this subject, in order to meet the work objectives.

\subsection{Models of Resource Selection in A/V E}

In table 2 a global analysis associated to the considered models $[44,45,46,47,48,49,50$, $51,52,53,54]$ is represented, in order to obtain a global view and draw an initial reference frame of the existent models.

Most of the models are qualitative/quantitative or quantitative type. In the first case they quantify several variables in analysis and have also a qualitative approach of some of these variables, or in the second case they express quantitatively all the considered variables in the respective mathematical model. One of the models found is exclusively qualitative [48]. Concerning to their graphical representation, some models use techniques like graphs of nodes [51], IDEF0 language [47] or a schematic representation of the model stages [46]. The mathematical models proposed opt in their great majority for integer programming proposing a resolution of the resource selection problem with complete enumeration algorithms; or goal programming (objective functions), breaking up the problem and defining objective functions for the considered variables. 


\begin{tabular}{|c|c|c|c|c|c|c|c|c|c|}
\hline \multirow{2}{*}{ Models } & \multirow{2}{*}{$\begin{array}{l}\text { Model } \\
\text { Type }\end{array}$} & \multicolumn{2}{|c|}{ Model Representation } & \multirow{2}{*}{$\begin{array}{l}\text { Decision- } \\
\text { Making } \\
\text { A/VE }\end{array}$} & \multirow{2}{*}{$\begin{array}{l}\text { A/VE Model } \\
\text { Associated }\end{array}$} & \multicolumn{2}{|c|}{$\begin{array}{l}\text { Task Plan } \\
\text { (TP) } \\
\text { Integration }\end{array}$} & \multirow{2}{*}{$\begin{array}{l}\text { Resource } \\
\text { Weighting }\end{array}$} & \multirow{2}{*}{$\begin{array}{l}\text { Value } \\
\text { Concept }\end{array}$} \\
\hline & & $\begin{array}{l}\text { Graphic } \\
\text { Repres. }\end{array}$ & Math. Model & & & $\begin{array}{l}\text { TP } \\
\text { Ref. }\end{array}$ & $\begin{array}{c}\text { TP } \\
\text { Eval. }\end{array}$ & & \\
\hline Sluga & Quantitative & Y & $\begin{array}{c}\text { Logic } \\
\text { Constraint } \\
\text { Programming }\end{array}$ & ND & ND & Y & $\mathrm{N}$ & $\mathrm{N}$ & $\mathrm{N}$ \\
\hline Ko & Quantitative & Y & $\begin{array}{c}\text { Integer } \\
\text { Programming }\end{array}$ & ND & ND & $\mathrm{N}$ & $\mathrm{N}$ & $\mathrm{N}$ & $\mathrm{N}$ \\
\hline Chu & $\begin{array}{l}\text { Qualitative/ } \\
\text { Quantitative }\end{array}$ & $\mathrm{N}$ & $\begin{array}{c}\text { Goal } \\
\text { Programming }\end{array}$ & ND & ND & Y & $Y$ & Y & $\mathrm{N}$ \\
\hline Ávila & $\begin{array}{l}\text { Qualitative/ } \\
\text { Quantitative }\end{array}$ & Y & $\begin{array}{c}\text { Goal } \\
\text { Programming } \\
\end{array}$ & ND & Y & Y & $\mathrm{N}$ & $\mathrm{N}$ & $\mathrm{N}$ \\
\hline Fischer & Qualitative & Y & $\begin{array}{c}\text { Goal } \\
\text { Programming }\end{array}$ & ND & Y & Y & $\mathrm{Y}$ & $Y / N D$ & $\mathrm{~N}$ \\
\hline Huang & $\begin{array}{l}\text { Qualitative/ } \\
\text { Quantitative }\end{array}$ & $\mathrm{Y}$ & $\begin{array}{c}\text { Goal } \\
\text { Programming }\end{array}$ & ND & ND & $\mathrm{N}$ & $\mathrm{N}$ & Y & $\mathrm{N}$ \\
\hline $\mathrm{Wu}$ & Quantitative & $\mathrm{Y}$ & $\begin{array}{c}\text { Integer } \\
\text { Programming }\end{array}$ & Y & ND & Y & Y & $\mathrm{N}$ & $\mathrm{N}$ \\
\hline Sha & $\begin{array}{l}\text { Qualitative/ } \\
\text { Quantitative }\end{array}$ & $\mathrm{N}$ & $\begin{array}{c}\text { Integer } \\
\text { Programming } \\
\end{array}$ & ND & ND & Y & ND & Y & $\mathrm{N}$ \\
\hline Zeng & Quantitative & $\mathrm{N}$ & $\begin{array}{c}\text { Integer } \\
\text { programming } \\
\text { NP complete }\end{array}$ & Y & ND & Y & ND & $\mathrm{N}$ & $\mathrm{N}$ \\
\hline Jarimo & $\begin{array}{l}\text { Qualitative/ } \\
\text { Quantitative }\end{array}$ & $\mathrm{N}$ & $\begin{array}{l}\text { Mixed Integer } \\
\text { Programming }\end{array}$ & ND & Y & Y & $\mathrm{Y}$ & Y & Y \\
\hline Chen & $\begin{array}{l}\text { Qualitative/ } \\
\text { Quantitative }\end{array}$ & $\mathrm{N}$ & Polynomial & ND & ND & $\mathrm{N}$ & ND & $\mathrm{N}$ & $\mathrm{N}$ \\
\hline
\end{tabular}

Table 2. Analysis of the Resource Selection Models for A/V E.

None of the models contemplates the decisionmaking for A/VE through a comparative analysis with a conventional process. The references to this decision have to see with the determination of the project accomplishment face to the selected resources and eventual constraints of the model $[50,52]$. We also conclude that the majority are not associated in an explicit form to A/VE reference models.

The integration of models with the task plan is not approached by all models, despite this issue gather some consensus relating to its importance. Each model handles this distinctly from the others. Concerning the weighting of the resources there are several models that incorporate this issue. A key aspect of the analysis and qualification of the models found has to do with the reference and incorporation of the value concept in these models. There is an almost total absence, with the sole exception one model where a brief reference is made indirectly [53]. This analysis reveals that there exists a fundamental paradigm nowadays, value creation, almost totally lacking in the literature of existing models of the resource selection process $[55,56]$. 
3.2 Pre-Selection Phase in the Resource Selection Models in AN E

During the pre-selection phase, the process runs, briefly, in the following manner: the tasks and their requisites are defined and communicated for the pre-selecting resources eligible (bid solicitation). The candidate resources respond and carry out their bids for each task (reception). The bids are then reviewed and either accepted or rejected (analysis/evaluation). The resources accepted after evaluation, i.e., the pre-selected resources, are then submitted to the final selection.

The pre-selection requisites that were considered in the analysis of the existent models are: Product/Task, Product/Task Project, Production Process and Production Planning.

The resource pre-selection process, in our AVE model, has the following phases [57]:

Resource Search: Identification of the resources that have potential to be pre-selected. The set of eligible resources consists of the resources potentially interested in its participation in the AVE tasks execution;
Automatic Identification: Consists in proceeding in real time to the comparison of the pre-selection requisites with the resource parameters and in pre-select the resources whose parameters satisfy the requisites;

Indirect Negotiation: Offer of the tasks and their pre-selection requisites to the eligible resources. The interested resources make their proposals for each task. The proposals are reviewed and accepted/refused;

Direct Negotiation: Consists in negotiating directly with the eligible resources their proposals considering the pre-selection requisites.

From table 3 , it can be emphasized that some models do not include this phase of pre-selection formally and even those who consider this phase, they just attend to some of the requisites associated to this phase. The existing models have neglected the pre-selection phase, incorporating it in the final selection. We consider that this is an important limitation because this is a fundamental phase to the success of an A/VE project.

\begin{tabular}{|c|c|c|c|c|c|c|c|c|c|}
\hline \multirow{2}{*}{ Models } & \multicolumn{4}{|c|}{ Resource Pre-Selection Phases } & \multirow{2}{*}{$\begin{array}{l}\text { Consider } \\
\text { Pre- } \\
\text { Selection }\end{array}$} & \multicolumn{4}{|c|}{ Pre-Selection Requisites } \\
\hline & $\begin{array}{l}\text { Resource } \\
\text { Search }\end{array}$ & $\begin{array}{l}\text { Automatic } \\
\text { Identification }\end{array}$ & $\begin{array}{l}\text { Indirect } \\
\text { Negotiation }\end{array}$ & Direct Negotiation & & Product/Task & $\begin{array}{l}\text { Product } \\
\text { /Task Project }\end{array}$ & $\begin{array}{l}\text { Production } \\
\text { Process }\end{array}$ & $\begin{array}{l}\text { Production } \\
\text { Planning }\end{array}$ \\
\hline Sluga & $\begin{array}{c}\text { Net } \\
\text { Diffusion }\end{array}$ & $\mathrm{N}$ & $\mathrm{Y}$ & $\mathrm{N}$ & $\mathrm{Y} / \mathrm{NE}$ & $Y$ & $\mathrm{~N}$ & $\mathrm{~N}$ & $Y$ \\
\hline Ko & $\begin{array}{c}\text { Net } \\
\text { Diffusion }\end{array}$ & $\mathrm{N}$ & $\mathrm{N}$ & $\mathrm{N}$ & $Y$ & $\mathrm{Y}$ & $Y$ & $Y$ & $\mathrm{~N}$ \\
\hline Chu & $\begin{array}{c}\text { Data } \\
\text { Bases, }\end{array}$ & $Y$ & $\mathrm{~N}$ & $\mathrm{Y}$ & Y & $\mathrm{Y}$ & $Y$ & Y & ND \\
\hline Ávila & $\mathrm{Y} / \mathrm{NE}$ & $\mathrm{Y} / \mathrm{NE}$ & $\mathrm{Y} / \mathrm{NE}$ & $\mathrm{Y} / \mathrm{NE}$ & $\mathrm{Y}$ & $\mathrm{Y}$ & $\mathrm{Y}$ & $\mathrm{Y}$ & $\mathrm{Y}$ \\
\hline Fischer & $\begin{array}{c}\text { Data } \\
\text { Bases }\end{array}$ & $\mathrm{N}$ & $\mathrm{N}$ & N & $\mathrm{Y} / \mathrm{NE}$ & $\mathrm{Y}$ & $\mathrm{Y}$ & Y & $\mathrm{Y}$ \\
\hline Huang & $\begin{array}{c}\text { Data } \\
\text { Bases }\end{array}$ & $\mathrm{N}$ & $Y$ & Y & ND & $\mathrm{N}$ & $\mathrm{N}$ & $\mathrm{N}$ & $\mathrm{N}$ \\
\hline $\mathbf{W u}$ & $\begin{array}{c}\text { Net } \\
\text { Diffusion }\end{array}$ & $\mathrm{N}$ & $\mathrm{Y}$ & $\mathrm{Y}$ & Y & Y & $\mathrm{Y}$ & Y & $\mathrm{Y}$ \\
\hline Sha & ND & $\mathrm{N}$ & $Y$ & $Y$ & $Y$ & $\mathrm{~N}$ & $\mathrm{~N}$ & $\mathrm{~N}$ & $Y$ \\
\hline Zeng & ND & $\mathrm{Y} / \mathrm{NE}$ & ND & ND & $\mathrm{N}$ & $\mathrm{N}$ & $\mathrm{N}$ & $\mathrm{N}$ & $\mathrm{N}$ \\
\hline Jarimo & ND & $\mathrm{N}$ & $Y$ & ND & ND & $Y$ & $Y$ & ND & ND \\
\hline Chen & $\begin{array}{l}\text { Data } \\
\text { Bases }\end{array}$ & $\mathrm{Y} / \mathrm{NE}$ & $\mathrm{N}$ & $N$ & ND & Y & Y & $\mathrm{N}$ & $\mathrm{N}$ \\
\hline
\end{tabular}

Legend: Y - Yes; ND - Not Defined; N - No; NE - Not Explicit

Table 3. Analysis of the Resource Pre-Selection Phase. 
We also conclude that considering the pre-selection phases, the resource search is the one where the existent models intervene. This phase is addressed in different ways, generally already incorporated in the final selection stage. Regarding the identification of the pre-selected resources (automatic identification, direct negotiation and indirect negotiation) only a few models attend all these phases, often in a non-formal or non-explicit way.

In our view, one of the main limitations of these models is that they do not attend to requisites associated with quality, financial and synergies aspects of resources. These requisites assume particular relevance because they are nowadays increasingly critical to the success of any project as we conclude in the analysis of conventional enterprises.

\subsection{Selection Phase in the Resource Selection Models in AN E}

For the creation and development of an Agile/Virtual Enterprise ( $A / V \quad E)$ the resource selection is a key phase. The resource selection models should be prepared to guarantee quality, efficiency and cost-attractiveness, in order to ensure the agility and integrability of the A/V E.

In this phase, the resource selection problem that integrates an $A / V E$, can be formulated as follow: knowing a plan of tasks with restrictions/requisites requested by the $A / V E$ promoter, and knowing the pre-selected resources, with its necessary data, for each task, the goal is to optimize a selection function that translates the better performance (or guarantees a good performance when it is not possible to certificate the optimal solution) of the selected resource system.

The selection requisites that were considered in the analysis of the existent models are: Number of Enterprises ( $\mathrm{N}^{\circ}$ Ent.), Production Time (Prod. Time), Transportation Time (Transp. Time), Production Cost (Prod. Cost), Transportation Cost (Transp. Cost), Resource Quality (Res. Quality) and Earliest Date (Earl. Date).

The resource selection process, in our $\mathrm{A} / \mathrm{V} \mathrm{E}$ model has three main phases [57]:

Evaluation of the Solution Space: Determination of the limits of the selection parameters and the solution space size in order to analyze the complexity of the selection problem and to evaluate how complex and/or feasible the project may be;

Selection and Integration of Selection Algorithms: Planning of the selection model that will be applied in the selection of system resources. We must select the most appropriate algorithms for each project and its associated requirements. Besides the algorithm selection, it is intended their integration or adaptation to the problem in question and to integrate them when more than one selection algorithm exists.

Final Selection System: Consists on the execution of the selection algorithms to find the best system of resources.

The resource selection process, in our $A / V E$ model, has two selection methods:

Independent Selection: Method that defines the system resources to integrate the $A / V$ E project depending on their total performance on all tasks of the TP;

Dependent Selection: Method that defines the resource system to integrate the $A / V$ E project according to their performance of executing tasks of the TP.

Table 4 represents the phases, the selection methods used, the requisites associated, and the selection tools used by the existent models.

The models treat the selection requisites in different ways. The requisite earliest date is not met in all models, a requisite which is increasingly essential when factors such as quickness and flexibility assume particular importance $[56,58,59]$. Also, the other requisites are treated differently by the models found, and none considers all the requisites presented. Only one of the models meets in a formal way the number of potential resource partners with the objective of minimizing the number of participating companies [54].

The analysis of the models also reveals that in the evaluation of the space solutions the models does not quantify the limits of the system performance. They only determine the size of the solution space in order to analyze whether the project may be feasible. Only one model includes a selection and integration of algorithms [47]. The other models specify their problems and propose a model/algorithm to solve or approach what we 
A Survey Analysis Of The Resource Selection Models In Agile/Virtual Enterprises, A. Pires et al. / 416-427

\begin{tabular}{|c|c|c|c|c|c|c|c|c|c|c|c|c|}
\hline \multirow[b]{2}{*}{ Models } & \multicolumn{3}{|c|}{ Phases } & \multirow{2}{*}{$\begin{array}{l}\text { Selection } \\
\text { Method }\end{array}$} & \multicolumn{7}{|c|}{ Requisites } & \multirow{2}{*}{$\begin{array}{l}\text { Final } \\
\text { Selection } \\
\text { Tools }\end{array}$} \\
\hline & $\begin{array}{c}\text { Evaluatio } \\
\text { n of the } \\
\text { Solution } \\
\text { Space }\end{array}$ & $\begin{array}{c}\text { Selection and } \\
\text { Integration of } \\
\text { Algorithms }\end{array}$ & $\begin{array}{c}\text { Final } \\
\text { Selection } \\
\text { System }\end{array}$ & & $\begin{array}{c}\mathbf{N}^{\circ} \\
\text { Ent. }\end{array}$ & $\begin{array}{l}\text { Prod. } \\
\text { Time }\end{array}$ & $\begin{array}{l}\text { Transp. } \\
\text { Time }\end{array}$ & $\begin{array}{l}\text { Prod. } \\
\text { Cost }\end{array}$ & $\begin{array}{c}\text { Transp. } \\
\text { Cost }\end{array}$ & $\begin{array}{c}\text { Res. } \\
\text { Quality }\end{array}$ & $\begin{array}{l}\text { Earl. } \\
\text { date }\end{array}$ & \\
\hline Sluga & Y & $\mathrm{N}$ & Y & $\begin{array}{c}\text { Dependent/ } \\
\text { Independent }\end{array}$ & $\mathrm{N}$ & Y & $\mathrm{N}$ & $Y$ & $N$ & N & Y & $B \& B$ \\
\hline Ko & ND & $\mathrm{N}$ & $\mathrm{Y}$ & $\begin{array}{l}\text { Dependent/ } \\
\text { Independent }\end{array}$ & $N$ & $\mathrm{~N}$ & $\mathrm{~N}$ & $Y$ & Y & $\mathrm{N}$ & $N$ & $\begin{array}{l}\text { Tabu } \\
\text { Search }\end{array}$ \\
\hline Chu & ND & $\mathrm{N}$ & $Y$ & Independent & ND & $Y$ & ND & $Y$ & Y & Y & ND & $\begin{array}{l}\text { AHP, } \\
\text { MADM }\end{array}$ \\
\hline Ávila & Y & Y & $\mathrm{Y}$ & $\begin{array}{l}\text { Dependent/ } \\
\text { Independent }\end{array}$ & ND & Y & $Y$ & $Y$ & Y & ND & ND & Option open \\
\hline Fischer & $\mathrm{Y}$ & $\mathrm{N}$ & $Y$ & Independent & ND & Y & ND & Y & Y & ND & Y & $\mathrm{AHP}, \mathrm{ACO}$ \\
\hline Huang & ND & $\mathrm{N}$ & $\mathrm{Y}$ & Independent & ND & Y & ND & $Y$ & ND & Y & Y & $\begin{array}{c}\text { Taguchi } \\
\text { Functions } \\
\end{array}$ \\
\hline Wu & Y & $\mathrm{N}$ & Y & $\begin{array}{l}\text { Dependent/ } \\
\text { Independent }\end{array}$ & ND & Y & $Y$ & $Y$ & Y & ND & Y & ECT \\
\hline Sha & Y & $\mathrm{N}$ & Y & Independent & ND & ND & ND & Y & ND & Y & ND & AHP, MAUT \\
\hline Zeng & Y & $\mathrm{N}$ & $\mathrm{Y}$ & Independent & ND & Y & ND & Y & ND & ND & Y & B\&B \\
\hline Jarimo & $\mathrm{Y}$ & $\mathrm{N}$ & $\mathrm{Y}$ & $\begin{array}{l}\text { Dependent/ } \\
\text { Independent }\end{array}$ & ND & Y & $Y$ & $Y$ & Y & ND & Y & EDR \\
\hline Chen & Y & $\mathrm{N}$ & $\mathrm{Y}$ & $\begin{array}{l}\text { Dependent/ } \\
\text { Independent }\end{array}$ & $\mathrm{Y}$ & ND & ND & ND & ND & ND & ND & $\begin{array}{l}\text { AHP, } \\
\text { MADM, } \\
\text { MAUT, } \\
\text { Fuzzy }\end{array}$ \\
\hline
\end{tabular}

Legend: Y - Yes; ND - Not Defined; N - No

Table 4. Analysis of the Resource Selection Phase.

consider the final selection of the resource system. Selection methods used by the models are often mixed (selection independent/dependent). They select the resource system that performs all tasks, which also has to be done task to task. Others approach only the independent selection. The tools/methods used for the resource selection system are of various types and may be characterized as support techniques to decision making.

\section{Conclusions}

We started this analysis with the selection models for conventional companies, with particular emphasis on a literature review on the subject, trying to create a synthesized frame of how this problem is treated. We found that authors divide the models into several categories. By analyzing these, we confirm that there is a myriad of methods and models used, which are applied to different types of problems. The analyzed selection models propose different approaches to this problem. New extents have also been incorporated in the selection models, according to the present market situation.

In which concerns to the overall process of resource/partners selection in AN E, the majority of the selection models for AV E is not explicitly linked to reference models. There is a whole variety of models, frameworks, methods, classifications and tools used, which leads us to mention the fact that this is an area that has been subject of intense research and where several types of approaches can be used.

Regarding the pre-selection, most models include this phase, although not always explicitly, only to 
meet some of the requisites associated with this phase. The pre-selection is addressed in different ways, sometimes not for the purpose of a preselection, but incorporated in the final selection phase. This pre-selection phase represents an important stage of the selection process that is not adequately explored and reasoned. It is worth noting that we do not find explicit and formal models that approached the pre-selection process in a detailed and systematic way. We identified gaps and limitations in this area and assessed the relevance of the development of our work. We think that in this area of the pre-selection of resources there will be space and relevance for a deeper and more efficient investigation that leads to a better integration of the whole process of the resource selection of an A/VE project.

The selection of the resource system is the main motivation of the presented models. The models treat the requisites of this selection phase in different ways and none considers all the requisites presented. This situation conditions the complexity and time to resolution of the selection algorithms inherent to the models and their performance. We also conclude that none of the models found in the existing literature incorporates formally the value concept, which indicates that there exists a fundamental gap that is not integrated in the problem inherent to the process of resource selection.

Neither of the models contemplates the decisionmaking stage to create an $A / V E$ through a comparative analysis with a conventional process. In our view, when the selection process is finished, and perhaps even at intermediate stages, an evaluation of that process should be made. This evaluation should include the costs and also other factors like the quality of the project, benefits from synergies and partnerships, financial situation and other aspects that will be developed with the A/V E project. This decision is important, we should consider whether it is worth regarding all these issues to proceed to the creation of an A/V E or if the project can be developed through a conventional process, possibly through outsourcing. Based on this comparison, which will involve several types of criteria, quantitative and qualitative, a reasoned decision must be made for creating an $\mathrm{A} / \mathrm{V} \mathrm{E}$.
We intend to work further along the theme of this pre-selection of resources and present an integration model of value analysis in the resource pre-selection process that has been developed and validated $[55,56,59]$. Further work will consider also recent, more advanced, models of A/VE such as "ubiquitous manufacturing systems" (UMS), "cloud manufacturing systems" (CMS), "social network-based manufacturing systems" (SNMS), the enterprise systems characterized by hypercomplex networks in which the resource selection models selection will be of special importance, including the models with the integrated value analysis, to be applied in all phases of the resources or partners.

\section{Acknowledgements}

The authors would like to thank the Fundação para a Ciência e Tecnologia (F.C.T.) for their support through: 1) the $\mathrm{PhD}$ grant award reference number SFRH/BD/37831/2007 to the author António Pires, 2) the financed project PTDC/EME-GIN/102143/2008, and 3) EUREKA, by project E!4177-Pro-Factory UES. 


\section{References}

[1] Sun Tzu, A Arte da Guerra, L\&PM Editores, 2000.

[2] Feldmann, K., Rottbauer, H., Roth, N., Relevance of Assembly in Global Manufacturing, Annals of CIRP, Vol.45/2, 1996, pp.545-552.

[3] Frayet, J-M., D’Amours, S., Monteuil, B., Cloutier, L., A Network Approach to Operate Agile Manufacturing Systems, International Journal of Production Economics, No.74, 2001, pp. 239-259.

[4] Butala, P., Sluga, A., Autonomous Work Systems in Manufacturing Networks, Annals of the CIRP Vol.55/1, 2006, pp.521-524.

[5] Drucker, P., The Emerging Theory of Manufacturing, Harvard Business Review, 1990, pp. 94-102.

[6] Nagel, R., Dove, R., 21st Century Manufacturing Enterprise Strategy. Bethlehem, Pennsylvania: lacocca Institute, Lehigh University, 1993.

[7] Putnik, G.D., BM_Virtual Enterprise Architecture Reference Model in Agile Manufacturing: 21st Century Manufacturing Strategy, Elsevier Science Publishers, 2000, pp. 73-93.

[8] Putnik, G.D., Cunha, M., Sousa, R., Ávila, P., BM_Virtual Enterprise: Model for Dynamics and Virtuality, in Virtual Enterprise Integration: Technological and Organizational Perspectives, IDEA Group, USA, Chapter VI, 2005, pp. 124-143.

[9] Putnik, G.D., Cunha, M. (Eds.), Knowledge and Technology Management in Virtual Organizations: Issues, Trends, Opportunities and Solutions, IDEA Group, USA, 2007.

[10] Aissaoui, N., Haouari, M., Hassini, E., Supplier Selection and Order Lot Sizing Modeling: A Review, Computers \& Operations Research, No.34, 2007, pp. 3516-3540.

[11] Benyoucef, L., Ding, H., Xie, X., Supplier Selection Problem: Selection Criteria and Methods, Institut National de Recherche en Informatique et en Automatique, No.4726, Feb., 2003.

[12] Figueira, J., Greco, S., Ehrgot, M., Multiple Criteria Decision Analysis: State of the Art Surveys, Springer International Series in Operations Research and Management Science, Springer Science + Business Media, NY, USA, 2005.
[13] Ng, W., An Efficient and Simple Model for Multiple Criteria Supplier Selection Problem, European Journal of Operational Research, No.186, 2008, pp. 1059-1067.

[14] Dulmin, R., Mininno, V., Supplier Selection using a Multi-Criteria Decision Aid Method, Journal of Purchasing \& Supply Management, No.9, 2003, pp. 177-187.

[15] Ghodsypour, S., O’Brien, C., A Decision Support System for Supplier Selection using an Integrated Analytic Hierarchy Process and Linear Programming, International Journal of Production Economics, No.56-57, 1998, pp. 199-212.

[16] Saen, R., A New Mathematical Approach for Suppliers Selection: Accounting for Non-Homogeneity is Important, Applied Mathematics and Computation, No.185, 2007, pp. 84-95.

[17] Zhang, H., Gen, M., Effective Genetic Approach for Optimizing Advanced Planning and Scheduling in Flexible Manufacturing System, GECCO'06, Seattle, USA, 2006, pp.1841-1848.

[18] Jenabi, M., Torabi, S., Mansouri, S., A Hybrid Genetic Algorithm for a Supply Chain Production Planning Problem, GECCO'07, London, United Kingdom, 2007, pp.2045-2052.

[19] Avasarala, V., An Approximate Algorithm for Resource Allocation using Combinatorial Auctions, Proceedings of the IEEE/WIC/ACM International Conference on Intelligent Agent Technology, 2006, pp.571-578.

[20] Lin, C., Chen, H., A Fuzzy Strategic Alliance Selection Framework for Supply Chain Partnering under Limited Evaluation Resources, Computers in Industry, Vol.55, 2004, pp. 159-179.

[21] Wang, J., Zhao, R., Tang, W., Fuzzy Programming Models for Vendor Selection Problem in a Supply Chain, Tsinghua Science \& Technology, Vol.13, No1, 2008, pp. 106-111.

[22] Amid, A., Ghodsypour, S., O'Brien, C., A Weighted Additive Fuzzy Multiobjective Model for the Supplier Selection Model under Price Breaks in a Supply Chain, International Journal of Production Economics, No.121, 2007, pp. 323-332.

[23] Humphreys, P., Wong, Y., Chan, F., Integrating Environmental Criteria into the Supplier Selection Process, Journal of Materials Processing Technology, No.138, 2003, pp. 349-356. 
[24] Liao, Z., Rittscher, J., A Multi-objective Supplier Selection Model under Stochastic Demand Conditions, International Journal of Production Economics, No.105, 2007, pp. $150-159$

[25] Weber, C., Current, J., Benton, W., Vendor Selection Criteria and Methods, European Journal of Operational Research, No. 50, 1991, pp. 2-18.

[26] Weber, C., Current, J., A Multi-objective Approach to Vendor Selection, European Journal of Operational Research, No. 68, 1993, pp. 173-184.

[27] Patton, W., Use of Human judgement models in Industrial buyers Vendor Selection Decisions, Industrial Marketing Management, vol.25, No.2, 1996, pp.135-149.

[28] Lehmann, D.R., Shaughnessy, O., Decision Criteria used in Buying Different Categories of Products, Journal of Purchasing and Materials Management, Vol.18, No.1, 1982, pp. 9-14.

[29] Talluri S., Narasimhan, R., Vendor Evaluation with Performance Variability: a Max-min Approach, European Journal of Operational Research, No.146, 2003, pp. 543-552.

[30] Renkema, T., The IT Value Quest: How to Capture the Business Value of IT-based Infrastructure, John Wiley \& Sons, Ltd., 1999, pp.164-201.

[31] Dyer, R., Foreman, E., Group Decision Support with the Analytic Hierarchy Process, Decision Support System, Vol.8, 1992, pp. 99-124.

[32] Halley, A., La Contribution dês Fournisseurs Privilegies à l'Integration dês la Chaine Logistique: mythe ou réalite?, Logistique et Management, Vol.8, No.1, 2000.

[33] Dickson, G., An Analysis of Vendor Selection: Systems and Decisions, Journal of Purchasing, Vol.1, No.2, 1966, pp. 5-17.

[34] Bei, W., Wang, S., Hu, J., An Analysis of Supplier Selection in Manufacturing Supply Management, International Conference on Service Systems and Service Management, 2006, pp. 1439-1444.

[35] Lin, X., Purchase, S., Investigating Supplier Selection using Repertory Grid Technique, IEEE International Conference on Service Operations and Logistics, and Informatics, 2006, pp. 432-435.

[36] Williams, O., Outsourcing. A ClO's perspective, CRC Press LLC, 1998.

[37] Ellran, L., The Supplier Selection Decision in Strategic Partnerships, Journal of Purchasing and Materials Management, 1990, pp. 8-14.
[38] Barbarosoglu, G., Yazgac, T., An Application of AHP to Supplier Selection Problem, Production and Inventory Management Journal, First quarter, 1997, pp. 14-21.

[39] Crow, L., Olshavsky, R., Summers, J., Industrial Buyer Choice Strategies: A Protocol Analysis, Journal of Marketing Research, Vol.17, 1980, pp. 34-44.

[40] Wright, P., Consumer Choice Strategies: Simplifying vs Optimising, Journal of Marketing Research, Vol.12, 1975, pp. 60-67.

[41] Timmerman, E., An Approach to Supplier Perfomance Evaluation, Journal of Purchasing and Materials Management, Vol.22, No.4, 1986, pp. 2-8.

[42] Holt G.D., Which Contractor Selection Methodology, International Journal of Project Management, No.16, 1998, pp. 153-164.

[43] Liu J., Fong, D., Lall, V., Using Data Envelopment Analysis to Compare Suppliers for Supplier Selection and Performance Improvement, International Journal of Supply Chain Management, No5, 2000, pp. 143-150.

[44] Sluga, A., Butala, P., Self-organization in Distributed Manufacturing System based on Constraint Logic Programming, Annals of CIRP, Vol.50, No.1, 2001, pp.35-46.

[45] Ko, C., Kim, T., Hwang H., External Partner Selection using Tabu Search Heuristics in Distributed Manufacturing, International Journal of Production Research, Vol.39, No.17, 2001, pp. 3959-3974.

[46] Chu, X., Tso, S., Zhang, W., Li, Q., Partnership Synthesis for Virtual Enterprises, International Journal of Advanced Manufacturing Technology, No.19, 2002, pp. 384-391.

[47] Ávila, P., Modelo Rigoroso de Selecção de Sistemas de Recursos para o Projecto de Empresas Ágeis/Virtuais para Produtos Complexos, Tese de Doutoramento, Universidade do Minho, 2004.

[48] Fischer, M., Jahn, H., Teich, T., Optimizing the Selection of Partners in Production Networks, Robotics \& Computer-Integrated Manufacturing, No.20, 2004, pp. 593-601.

[49] Huang, X., Wong, Y., Wang, J., A Two-Stage Manufacturing Partner Selection Framework for Virtual Enterprises, International Journal of Computer Integrated Manufacturing, Vol.17, No.4, 2004, pp. 294-304.

[50] Wu, N., Su, P., Selection of Partners in Virtual Enterprise Paradigm, Robotics \& Computer-Integrated Manufacturing, No.21, 2005, pp. 119-131. 
[51] Sha, D., Che, Z., Virtual Integration with a MultiCriteria Partner Selection Model for the Multi-Echelon Manufacturing System, International Journal of Advanced Manufacturing Technology, No.25, 2005, pp. 793-802.

[52] Zeng, Z., Li, Y., Zhu, W., Partner Selection with a Due Date Constraint in Virtual Enterprises, Applied Mathematics and Computation, No.175, 2006, pp. 1353-1365.

[53] Jarimo, T., Salo, A., Multicriteria Partner Selection in Virtual Organizations with Transportation Costs and Other Network Interdependencies; Transactions on Systems, Man and Cybernetics, Vol.39, 2009, pp. 684-693.

[54] Chen, Q., Chen, X., Lee, W., Qualitative Search Algorithms for Partner Selection and Task Allocation in the Formulation of Virtual Enterprise, International Journal of Computer Integrated Manufacturing, Vol.20, No.2-3, 2007, pp. 115-126.

[55] Pires, A., Putnik, G.D., Ávila, P., The Potentialities of the Application of Value Analysis, Proceedings of 24th International Manufacturing Conference, Waterford, Ireland, 2007, pp. 745-751.

[56] Ávila, P., Costa, L., Bastos, J., Lopes, P., Pires, A., Analysis of the Domain of Applicability of an Algorithm for a Resources System Selection Problem for Distributed/Agile/Virtual Enterprises Integration, Actas de la $5^{a}$ Conferencia Ibérica de Sistemas y Tecnologías de Información, Santiago Compostela, Vol.I, 2010, pp. 506-510.

[57] Ávila P., Putnik G.D., Cunha M., Pires A., Broker and Market of Resources as Organizational Mechanisms for Sustainability of Resources Selection Processes in Agile/Virtual Enterprises, Proceedings of SymOrg 2006 $X$ International Symposium, Belgrade/Zlatibor, Servia, 2006.

[58] Pires, A., Uma Reflexão sobre a Análise do Valor e o seu posicionamento no actual panorama da Gestão da Qualidade, Tese de Mestrado, Faculdade de Engenharia da Universidade do Porto, 2000.

[59] Pires A., Integração de Análise do Valor no Processo de Configuração de Empresas Ágeis/Virtuais, Unpublished PhD Thesis, Universidade do Minho, 2011. 